Siti Hartini , Eliya Mursyida / Jurnal Analis Kesehatan Klinikal Sains 7 (1) (2019)

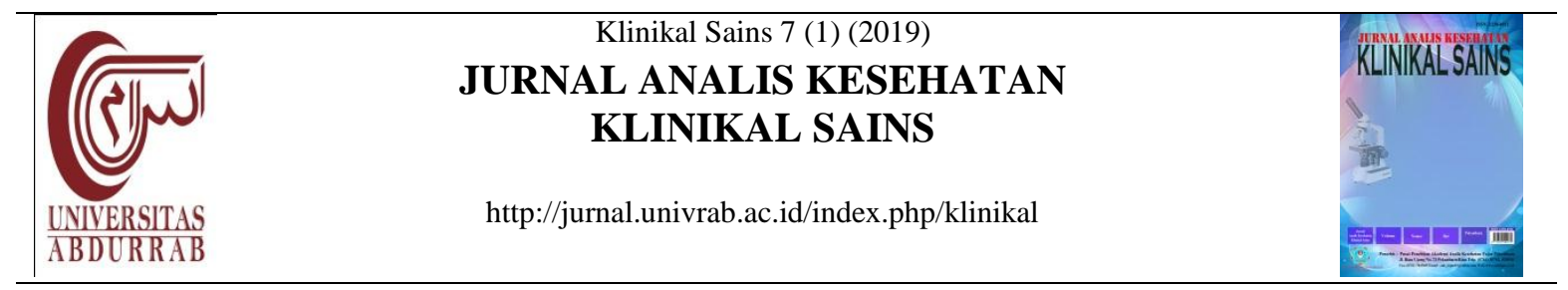

\title{
EFEKTIVITAS PEMBERIAN EKSTRAK DAUN PEPAYA (Carica papaya L) TERHADAP PERTUMBUHAN BAKTERI Escherichia coli dan Shigella dysenteriae
}

\author{
Siti Hartini dan Eliya Mursyida \\ Program Studi Pendidikan Dokter, Fakultas Kedokteran dan Ilmu Kesehatan, Universitas Abdurrab \\ Jalan Riau Ujung No. 73, Pekanbaru \\ E-mail: eliya_mursyida@univrab.ac.id
}

\begin{abstract}
Info Artikel
Abstrak

Sejarah Artikel:

Diterima Januari 2019

Disetujui April 2019

Dipublikasikan Juni 2019

Escherichia coli (E. coli) dan Shigella dysenteriae (S. dysenteriae) merupakan bakteri penyebab diare. Salah satu tumbuhan yang dapat digunakan sebagai pengobatan untuk diare adalah daun pepaya. Daun papaya memiliki kandungan senyawa aktif seperti papain, tanin, alkaloid, flavonoid, fenol, saponin, dan steroid yang diduga memiliki efek antimikroba. Penelitian ini bertujuan untuk menganalisis efektivitas pemberian

Keywords: antimikroba, daun

Escherichia Shigella dysenteriae ekstrak daun pepaya (Carica papaya L.) dengan berbagai konsentrasi terhadap ekstrak pertumbuhan bakteri $E$. coli dan $S$. dysenteriae. Penelitian ini menggunakan pepaya, rancangan post-test only with control group dengan metode difusi kertas cakram

coli, (Kirby-Bauer). Zona hambat yang terbentuk diukur menggunakan jangka sorong dan dianalisis menggunakan uji One Way ANOVA. Hasil penelitian menunjukkan bahwa ekstrak daun papaya dapat menghambat pertumbuhan bakteri $E$. coli dan $S$. dysenteriae secara in-vitro. Analisis uji statistika didapatkan $(\mathrm{p}<0,05)$ yang artinya terdapat perbedaan nyata antar kelompok perlakuan setelah pemberian ekstrak daun pepaya terhadap pertumbuhan bakteri E. coli dan $S$. dysenteriae.
\end{abstract}

Kata Kunci: antimikroba, ekstrak daun pepaya, Escherichia coli, Shigella dysenteriae

\begin{abstract}
Escherichia coli (E. coli) and Shigella dysenteriae ( $S$. dyseteriae) are the causative bacteria for diarrhea. One of the plants that can be used as a treatment for diarrhea is papaya leaves. Papaya leaves contain active compounds such as papain, tannins, alkaloids, flavonoids, phenols, saponins and steroids which are thought to have antimicrobial effects. This study aims to analyze the effectiveness of giving papaya leaf extract (Carica papaya L.) with various concentrations on the growth of E. coli and $S$. dysenteriae bacteria. This study uses a post-test only design with control group with the disc paper diffusion method (Kirby-Bauer). The inhibition zone formed was measured using calipers and analyzed using the One Way Anova test. The result showed that papaya leaf extract colud inhibit the growth of E. coli and $S$. dysenteriae bacteria in vitro. Analysis of statistical tests was obtained $(\mathrm{p}<0,05)$ which means there were significant differences between treatment groups after the administration of papaya leaf extract on the growth of E. coli and $S$. dysenteriae bacteria.
\end{abstract}

Keywords: antimicrobial, papaya leaf extract, Escherichia coli, Shigella dysenteriae 
Siti Hartini , Eliya Mursyida / Jurnal Analis Kesehatan Klinikal Sains 7 (1) (2019)

(C) 2019 Universitas Abdurrab

Alamat korespondensi:

ISSN 2338-4921

Jalan Riau Ujung No. 73, Pekanbaru

E-mail: eliya_mursyida@univrab.ac.id

\section{PENDAHULUAN}

Diare adalah gangguan buang air besar (BAB) yang ditandai dengan BAB lebih dari tiga kali dalam sehari dengan konsistensi feses cair atau encer, dapat disertai dengan darah dan/atau lendir (Kementerian Kesehatan, 2013). Diare merupakan penyebab kematian kedua pada anak usia $<5$ tahun akibat terjadinya dehidrasi yang berat, serta hilangnya banyak cairan (World Health Organization, 2017). Di Indonesia, diare termasuk penyakit endemis dan juga merupakan penyakit potensial Kejadian Luar Biasa (KLB) yang sering disertai dengan kematian (Kementerian Kesehatan, 2017).

Pada tahun 2016, terjadi 3 kali KLB diare yang tersebar di tiga Provinsi di Indonesia, yaitu Provinsi Nusa Tenggara Timur Kabupaten Kupang sebanyak 170 kasus dan 3 kematian, Provinsi Jawa Tengan Kabupaten Purworejo sebanyak 56 kasus dan 3 kematian, dan Provinsi Sumatera Utara Kabupaten Binjai sebanyak 35 kasus dengan jumlah keseluruhan penderita sebanyak 198 orang dan kematian sebanyak 6 orang (Kementerian Kesehatan, 2017).

Diare pada umumnya disebabkan oleh beberapa mikroba, salah satunya infeksi yang disebabkan oleh bakteri. Bakteri yang paling sering menyebabkan diare antara lain: Campylobacter jejuni, Clostridium difficile, Escherichia coli, Shigella dysenteriae, Salmonella thypi, S. parathypi, Staphylococcus aureus, dan Vibrio cholerae (Koletzko and Osterrieder, 2009; Saeed, Abd and Sandstrom, 2015). Bakteri Escherichia coli (E. coli) dan Shigella dysenteriae (S. dysenteriae) termasuk ke dalam bakteri Gram negatif, bentuk batang pendek, serta bersifat fakultatif anaerob. E. coli merupakan flora normal pada saluran pencernaan yang kadang dapat menjadi patogen jika jumlah bakteri meningkat atau saat daya tahan tubuh pejamu melemah, sedangkan $S$. dysenteriae termasuk bakteri penyebab patogen pada manusia. E. coli dan $S$. dysenteriae mampu menghasilkan toksin yang terikat pada mukosa usus sehingga menyebabkan diare (Brooks et al., 2012).

Diare yang disebabkan bakteri E. coli dan $S$. dysenteriae umumnya dapat diobati dengan antibiotik spektrum luas seperti siprofloksasin, kotrimoksazol, dan eritromisin (Setiati et al., 2014). Di Indonesia, intensitas penggunaan antibiotik relatif tinggi dan tidak rasional. Berdasarkan data Riset Kesehatan Dasar (2013), sekitar 86\% penduduk Indonesia masih menyimpan antibiotik tanpa resep untuk pengobatan sendiri di rumah. Beberapa Provinsi yang masih menyimpan antibiotik tanpa resep di rumah antara lain, Provinsi Kalimantan Tengah (93,4\%), Provinsi Riau (87,3\%), Provinsi Lampung (90,5\%), dan Provinsi Gorontalo (74,7\%) 
Siti Hartini , Eliya Mursyida / Jurnal Analis Kesehatan Klinikal Sains 7 (1) (2019)

(Kementerian Kesehatan, 2013). Akibat penggunaan antibiotik yang relatif tinggi maka timbul permasalahan tentang efek antibiotik sendiri seperti terjadinya alergi dari ringan sampai berat (Shehab et al., 2016).

Indonesia merupakan salah satu negara yang menduduki peringkat kedua dengan banyak penghasil sumber daya alam (SDA). Sebanyak 40.000 jenis tumbuh-tumbuhan yang telah dikenal di dunia, Indonesia memiliki sekitar 30.000 jenis tumbuhan yang mana jumlah tersebut mewakili 90\% dari tumbuhan obat yang terdapat di wilayah Asia dan sekitar 7500 jenis dimanfaatkan sebagai obat herbal (BPOM RI, 2017). Obat herbal merupakan warisan turun-temurun dari nenek moyang yang berakar kuat dalam budaya bangsa, oleh karena itu baik dalam ramuan maupun penggunaannya dalam pengobatan tradisional masih berdasarkan pengalaman yang diturunkan dari generasi ke generasi, baik secara lisan maupun tulisan (Riswan and Andayaningsih, 2008). Beberapa tumbuhan yang digunakan masyarakat luas sebagai obat herbal antara lain, daun mahkota dewa (Tone, Wuisan and Mambo, 2013), daun pepaya (Nirosha and Mangalanayaki, 2013), daun cengkeh (Sidabutar, Kairupan and Durry, 2016), dan sebagainya.

Daun pepaya merupakan salah satu tumbuhan yang digunakan oleh masyarakat luas dalam mengobati diare (Sugito and Suwandi, 2017). Penelitian yang dilakukan Vijayakumar et al., (2015) dan Adeniyi et al., (2011), mengatakan bahwa daun pepaya memiliki beberapa senyawa antimikroba seperti papain, tanin, alkaloid, flavonoid, fenol, saponin, dan steroid dalam menhambat pertumbuhan bakteri Bacillus subtilis, Salmonella typhi, Pseudomonas fluorescens, Clostridium tetani, Escherichia coli, Proteus vulgaris, Staphylococcus aureus, dan Shigella dysenteriae (Adeniyi and Elizabeth, 2011; Vijayakumar, Bharathidasan and Prince, 2015). Rahayu et al., (2016) juga mengatakan bahwa daun pepaya memiliki manfaat dalam pengobatan yang sangat beragam karena kandungan senyawa aktif seperti papain, karotenoid, alkaloid, monoterpenoid, flavonoid, mineral, vitamin, glukosinolat, dan karposida yang diduga berperan sebagai antikanker, antioksidan, antidiabetes, antiinflamasi, antibakteri, antimalaria, antidengue, dan penyembuh luka (Rahayu and Tjitraresmi, 2016).

Berdasarkan latar belakang tersebut, maka peneliti tertarik ingin meneliti pengaruh pemberian ekstrak daun pepaya terhadap pertumbuhan bakteri. Penelitian ini bertujuan menganalisis pengaruh pemberian ekstrak daun pepaya dengan berbagai konsentrasi terhadap pertumbuhan bakteri $E$. coli dan $S$. dysenteriae, yang nantinya dapat memberi informasi, pengetahuan, serta bukti ilmiah kepada masyarakat tentang pentingnya daun pepaya dalam mengobati penyakit infeksi.

\section{METODE}


Siti Hartini , Eliya Mursyida / Jurnal Analis Kesehatan Klinikal Sains 7 (1) (2019)

Jenis penelitian ini adalah eksperimental yang dilakukan secara in-vitro dengan post test only with control group untuk menganalisa pengaruh pemberian ekstrak daun pepaya konsentrasi 25\%, 50\%, 75\%, dan 100\% terhadap pertumbuhan bakteri E. coli dan S. dysenteriae. Penelitian ini dilaksanakan pada bulan Mei hingga Juni 2018, bertempat di Laboratorium Sekolah Tinggi Farmasi (STIFAR) Pekanbaru.

Alat yang digunakan pada penelitian ini antara lain: autoklaf, bola hisap, cawan petri, batang pengaduk, bunsen, inkubator, oven, Erlenmeyer, labu ukur, gelas ukur, gelas beker, tabung reaksi, mikropipet, pinset, ose bulat, lidi kapas steril, handscoen, pipet tetes, masker, marker, neraca, spatula, rak tabung reaksi, botol semprot, dan pipet ukur. Bahan yang digunakan pada penelitian ini yaitu: daun pepaya muda yang diperoleh dari perkebunan pepaya sekitar jalan Garuda Kecamatan Payung Sekaki Kota Pekanbaru, isolat bakteri E. coli dan S. dysenteriae yang diperoleh dari Laboratorium Bakteriologi SMK Analisis Kesehatan Abdurrab Pekanbaru, $\mathrm{NaCl}$ 0,9\%, etanol 96\%, medium Muller-Hinton Agar (MHA), spiritus, larutan $\mathrm{BaCl}_{2} 1 \%$, larutan $\mathrm{H}_{2} \mathrm{SO}_{4} 1 \%$, kertas cakram, dan antibiotik meropenem dan siprofloksasin.

\section{Prosedur Kerja}

\section{Pembuatan Ekstrak Daun Pepaya}

Daun pepaya dicuci bersih dan dipotong-potong kecil, lalu dikeringkan dibawah sinar matahari hingga didapat sampel kering. Selanjutnya, diblender hingga halus menjadi serbuk, kemudian dimaserasi menggunakan pelarut etanol 96\%, lalu didiamkan selama 24 jam. Setelah itu, larutan disaring untuk memperoleh filtrat dan memisahkannya dari ampas. Ampas yang diperoleh dimaserasi kembali dengan prosedur yang sama sebanyak 3 kali untuk memastikan bahwa senyawa-senyawa yang terkandung dalam sampel kering telah diperoleh dengan sempurna. Selanjutnya, ekstrak dipekatkan menggunakan rotary evaporator hingga didapatkan ekstrak kental.

\section{Uji Sensitifitas Bakteri dengan Metode Kirby-Bauer}

Suspensi bakteri E. coli dan S. dysenteriae yang sudah sesuai dengan standar McFarland 0,5\%, diambil menggunakan kapas lidi steril, kemudian diswab pada medium MHA. Setelah itu, sebanyak 6 kertas cakram steril diletakkan pada cawan petri, kemudian ditetesi dengan berbagai konsentrasi ekstrak etanol daun pepaya serta $\mathrm{NaCl} 0,9 \%$ untuk kontrol negatif dan antibiotik meropenem untuk kontrol positif $E$. coli dan antibiotik siprofloksasin untuk kontrol positif $S$. dysenteriae, kemudian diinkubasi selama 24 jam pada suhu $35^{\circ} \mathrm{C}$. Selanjutnya, diamati dan diukur diameter zona hambat yang terbentuk dengan menggunakan jangka sorong. Penelitian ini dilakukan sebanyak tiga kali pengulangan. 


\section{HASIL DAN PEMBAHASAN}

Tabel 1 menunjukkan bahwa ekstrak etanol daun pepaya dapat menghambat pertumbuhan bakteri E. coli dan S. dysenteriae, dimana diameter zona hambat terbesar ditunjukkan oleh konsentrasi $100 \%$ yaitu masing-masing sebesar $18,67 \mathrm{~mm}$ dan $18,33 \mathrm{~mm}$, sedangkan zona hambat terkecil ditunjukkan oleh konsentrasi $25 \%$ yaitu masing-masing sebesar $8,67 \mathrm{~mm}$ dan $8,00 \mathrm{~mm}$.

Tabel 1. Hasil Diameter Zona Hambat Bakteri E. coli dan S. dysenteriae

\begin{tabular}{cccccc}
\multicolumn{2}{c}{ Perlakuan } & N & Mean \pm SD & Min & Max \\
\hline \multirow{4}{*}{ E. coli } & $25 \%$ & 3 & $8,67 \pm 0,5$ & 8,00 & 9,00 \\
& $50 \%$ & 3 & $12,00 \pm 1,00$ & 11,00 & 13,00 \\
& $75 \%$ & 3 & $15,00 \pm 1,00$ & 14,00 & 16,00 \\
& $100 \%$ & 3 & $18,67 \pm 0,57$ & 18,00 & 19,00 \\
\hline \multirow{3}{*}{ S. } & $25 \%$ & 3 & $8,00 \pm 1,00$ & 7,00 & 9,00 \\
dysenteriae & $50 \%$ & 3 & $11,00 \pm 1,00$ & 10,00 & 12,00 \\
& $75 \%$ & 3 & $13,33 \pm 0,57$ & 13,00 & 14,00 \\
& $100 \%$ & 3 & $18,33 \pm 0,57$ & 18,00 & 19,00 \\
\hline
\end{tabular}

Hasil uji normalitas diperoleh bahwa data terdistribusi normal $(\mathrm{P}>0,05)$ dan uji homogenitas menunjukkan data homogen $(\mathrm{P}>0,05)$. Pada hasil uji One Way Anova terlihat bahwa terdapat perbedaan antar kelompok perlakuan ekstrak etanol daun pepaya (Carica papaya L.) terhadap pertumbuhan bakteri E. coli dan S. dysenteriae dengan nilai signifikan $(\mathrm{P}<0,05)$. Hasil uji Post hoc Bonferroni menunjukkan bahwa terdapat perbedaan nyata yang lebih kecil antar kelompok perlakuan yaitu $25 \%, 50 \%, 75 \%$, dan $100 \%$ terhadap pertumbuhan bakteri E. coli dan $S$. dysenteriae dengan nilai yang signifikan $(\mathrm{P}<0,05)$ (Tabel 3).

Tabel 2. Hasil uji One Way Anova terhadap E. coli dan S. dysenteriae

\begin{tabular}{cccccc}
\hline & & $\mathrm{df}$ & $\begin{array}{c}\text { Mean } \\
\text { Square }\end{array}$ & $\mathrm{F}$ & $\mathrm{P}$ value \\
\hline \multirow{3}{*}{ E. coli } & Between Groups & 3 & 54.528 & 81.792 & .001 \\
& Within Groups & 8 & .667 & & \\
& Total & 11 & & & \\
\hline \multirow{2}{*}{ S. } & Between Groups & 3 & 57.111 & 85.667 & .001 \\
dysenteriae & Within Groups & 8 & .667 & & \\
& Total & 11 & & & \\
\hline
\end{tabular}

Tabel 3. Perbandingan Ekstrak Etanol Daun Pepaya Berbagai Konsentrasi Terhadap E. coli dan S. dysenteriae dengan uji Post hoc Bonferroni P value 
Siti Hartini , Eliya Mursyida / Jurnal Analis Kesehatan Klinikal Sains 7 (1) (2019)

\begin{tabular}{cccccc} 
& Perlakuan (\%) & $\mathbf{2 5}$ & $\mathbf{5 0}$ & $\mathbf{7 5}$ & $\mathbf{1 0 0}$ \\
\hline \multirow{3}{*}{ E. coli } & 25 & & 0,006 & 0,000 & 0,000 \\
& 50 & & & 0,012 & 0,000 \\
& 75 & & & & 0,003 \\
& 100 & & & & \\
\hline \multirow{4}{*}{ S. dysenteriae } & 25 & & 0,012 & 0,000 & 0,000 \\
& 50 & & & 0,048 & 0,000 \\
& 75 & & & & 0,000 \\
\hline
\end{tabular}

Hasil pada penelitian ini menunjukkan bahwa pemberian ekstrak etanol daun pepaya (Carica papaya $L$ ) dengan berbagai konsentrasi mampu menghambat pertumbuhan bakteri E. coli dan S. dysenteriae yang ditunjukkan dengan terbentuknya zona hambat di sekitar kertas cakram. Penelitian ini sesuai dengan penelitian yang dilakukan oleh Tuntun (2016) dan Yunika (2015) yang mendapatkan bahwa ekstrak etanol daun pepaya (Carica papaya $L$ ) mampu menghambat pertumbuhan E. coli dan S. dysenteriae (Yunika, 2015; Tuntun, 2016). Hal ini dikarenakan daun pepaya memiliki senyawa aktif yang dapat menghambat pertumbuhan bakteri antara lain, flavonoid, tanin, alkaloid, steroid, saponin, dan triterpenoid dari pelarut air (A'yun and Laily, 2015). Menurut Astuti (2009) senyawa aktif daun pepaya yang terlarut dengan menggunakan pelarut etanol diantaranya yaitu flavonoid, alkaloid, dan saponin (Astuti, 2009).

Flavonoid bekerja dengan cara membentuk ikatan hidrogen untuk menghambat pembentukan DNA, RNA, dan menghambat enzim ATPase bakteri. Flavonoid juga menghambat sitokrom $\mathrm{C}$ reduktase sehingga proses biosintesis dan makromolekul terganggu (Cushnie, Cushnie and Lamb, 2014). Pratiwi et al (2015) menyebutkan bahwa tanin bekerja dengan cara menginaktivasi adhesin bakteri dan menginaktivasi enzim hidrolitik seperti protease dan karbohidrolase, serta menghambat enzim pada protein transpor selubung sehingga sel bakteri tidak dapat terbentuk (Pratiwi, Praharani and Arina, 2015).

Alkaloid memiliki gugus basa yang dapat bereaksi dengan DNA bakteri, sehingga merusak DNA bakteri yang menyebabkan rusaknya inti sel bakteri. Kerusakan sel membuat bakteri tidak mampu melakukan metabolisme sehingga mengalami lisis, dengan demikian bakteri menjadi inaktif dan hancur (Tuntun, 2016). Mekanisme kerja saponin sebagai antibakteri yaitu dengan cara menurunkan tegangan permukaan yang mengakibatkan naiknya permeabilitas dan kebocoran sel sehingga senyawa intraseluler akan keluar. Menurut Cavaleri et a.,l (2005) senyawa ini berdifusi melalui membran luar dan dinding sel yang rentan, lalu mengikat membran sitoplasma dan mengurangi kestabilan membran. Sehingga menyebabkan kebocoran pada sitoplasma yang mengakibatkan kematian sel (Cavaleri et al., 2005). 
Siti Hartini , Eliya Mursyida / Jurnal Analis Kesehatan Klinikal Sains 7 (1) (2019)

Pada penelitian yang dilakukan diameter zona hambat yang terbentuk lebih besar dibandingkan dengan penelitian sebelumnya, dimana Tuntun (2016) mendapatkan bahwa ekstrak etanol daun pepaya konsentrasi $20 \%$ sampai $100 \%$ mampu menghambat pertumbuhan bakteri $E$. coli dengan diameter zona hambat sebesar $6,5 \mathrm{~mm}$ sampai $9,1 \mathrm{~mm}$. Hal ini kemungkinanan dikarenakan pada penelitian Tuntun (2016) menggunakan daun pepaya tua, sedangkan pada penelitian yang dilakukan menggunakan daun pepaya muda. Menurut Gogna et al., (2015) daun pepaya muda memiliki kandungan senyawa flavonoid paling tinggi dibanding daun pepaya tua (Gogna, Hamid and Dorai, 2015). Penelitian yang dilakukan Sugito dan Suwandi (2017) menunjukkan bahwa ekstrak daun pepaya konsenstrasi 12\% sampai 20\% mampu menghambat pertumbuhan bakteri $E$. coli dengan diameter zona hambat sebesar 10mm sampai $14 \mathrm{~mm}$ (Sugito and Suwandi, 2017). Pada penelitian yang dilakukan diameter zona hambat lebih kecil dibanding penelitian Sugito dan Suwandi (2017) yang memiliki diameter zona hambat lebih besar dari konsentrasi $12 \%$ sampai $100 \%$. Hal ini dapat disebabkan oleh adanya beberapa faktor yang mempengaruhi terbentuknya zona hambat seperti kecepatan difusi, stabilitas bahan antimikroba, dan jumlah organisme yang diinokulasi (Fadhyla, 2013).

Penelitian yang dilakukan Yunika (2015) menunjukkan bahwa zona hambat yang terbentuk setelah pemberian ekstrak daun pepaya terhadap pertumbuhan bakteri $S$. dysenteriae pada konsentrasi 10\%, 15\%, dan 20\% diameter zona hambat yang terbentuk sebesar 6mm, 10mm, dan $17 \mathrm{~mm}$. Berbeda dengan penelitian yang dilakukan dimana diameter zona hambat yang dihasilkan lebih kecil dibanding penelitian yang dilakukan Yunika (2015). Hal ini dikarenakan pada penelitian yang dilakukan menggunakan metode difusi agar sedang penelitian sebelumnya menggunakan metode difusi agar (sumur). Menurut Anggraini et al., (2013) adanya perantara kertas cakram menyebabkan senyawa antimikroba pada daun pepaya lebih sulit untuk berdifusi ke dalam agar. Pada metode difusi agar (sumur), senyawa antimikroba ekstrak daun pepaya muda berdifusi langsung ke agar, karena ekstrak dimasukkan ke dalam sumur agar sehingga senyawa aktif dapat langsung bekerja melawan bakteri tanpa hambatan (Anggraini, Roza and Fitmawati, 2013).

\section{SIMPULAN}

Berdasarkan hasil penelitian diperoleh kesimpulan bahwa terdapat pengaruh pemberian esktrak etanol 96\% daun pepaya (Carica papaya $L$.) terhadap pertumbuhan bakteri E. coli dan $S$. dysenteriae pada konsentrasi 25\%, 50\%, 75\%, dan 100\%. Ekstrak etanol $96 \%$ daun pepaya memiliki daya hambat tertinggi terhadap pertumbuhan bakteri E. coli dan S. dysenteriae pada konsentrasi $100 \%$ dengan diameter zona hambat masing masing sebesar $18,6 \mathrm{~mm}$ dan $18,3 \mathrm{~mm}$ 
Siti Hartini, Eliya Mursyida / Jurnal Analis Kesehatan Klinikal Sains 7 (1) (2019)

dan daya hambat terendah pada konsentrasi $25 \%$ dengan diameter zona hambat masing-masing sebesar $8,6 \mathrm{~mm}$ dan $8 \mathrm{~mm}$.

\section{DAFTAR PUSTAKA}

A’yun, Q. and Laily, A. N. (2015) 'Analisis Fitokimia Daun Pepaya (Carica papaya L.) Di Balai Penelitian Tanaman Aneka Kacang dan Umbi, Kendalpayak, Malang', Prosiding KPSDA, 1(1), pp. 134-137.

Adeniyi, O. A. and Elizabeth, O. T. (2011) 'Comparative Study of Antibacterial Activities of Ethanol Extracts of the Bark and Seeds of Garcinia kola and Carica papaya', Afr. J. Biomed. Res, 14(2), pp. 147-152.

Anggraini, D. N., Roza, R. M. and Fitmawati (2013) 'Aktivitas Antibakteri Esktrak Daun Pepaya (Carica papaya L.) Terhadap Pertumbuhan Escherichia coli dan Salmonella typhi'. Pekanbaru.

Astuti, S. D. (2009) 'Efek Ekstrak Etanol 70\% Daun Pepaya (Carica papaya, Linn.) terhadap Aktivitas AST dan ALT pada Tikus Galur Wistar setelah Pemberian Obat Tuberkulosis (Isoniazid \& Rifampisin)', Skripsi. Surakarta: Fakultas Farmasi Universitas Setia Budi Surakarta.

BPOM RI (2017) 'Ramuan Pusaka Nusantara, Kekayaan Bangsa yang Harus Dipelihara'. Jakarta. Brooks, G. et al. (2012) Jawetz Melnick\&Adelbergs Medical Microbiology 26/E. 26th edn. McGraw-Hill Education. Available at: https://books.google.co.id/books?id=OY3DUKbcopAC.

Cavaleri, J. et al. (2005) 'Manual of Antimicrobial Susceptibility Testing', American Society for Microbiology, Seattle, Washington, 12, pp. 42-53.

Cushnie, T. P. T., Cushnie, B. and Lamb, A. J. (2014) 'Alkaloids: An Overview of Their Antibacterial, Antibiotic-Enhancing and Antivirulence Activities', International Journal of Antimicrobial Agents. Elsevier, 44(5), pp. 377-386.

Fadhyla, A. (2013) 'Pengaruh Ekstrak Daun Pepaya (Carica papaya L.) Terhadap Pertumbuhan Bakteri Plak Porphyromonas gingivalis (Kajian in vitro)'. Yogyakarta: Universitas Gadjah Mada.

Gogna, N., Hamid, N. and Dorai, K. (2015) 'Metabolomic Profiling of the Phytomedicinal Constituents of Carica papaya L. Leaves and Seeds by 1H NMR Spectroscopy and Multivariate Statistical Analysis', Journal of pharmaceutical and biomedical analysis. Elsevier, 115, pp. 74-85.

Kementerian Kesehatan, R. I. (2013) 'Riset Kesehatan Dasar 2013'. Jakarta.

Kementerian Kesehatan, R. I. (2017) 'Profil Kesehatan Indonesia 2016'. Jakarta. 
Siti Hartini, Eliya Mursyida / Jurnal Analis Kesehatan Klinikal Sains 7 (1) (2019)

Koletzko, S. and Osterrieder, S. (2009) 'Acute Infectious Diarrhea in Children', Deutsches Ärzteblatt International. Deutscher Arzte-Verlag GmbH, 106(33), p. 539.

Nirosha, N. and Mangalanayaki, R. (2013) 'Antibacterial Activity of Leaves and Stem Extract of Carica papaya L', International Journal of Advances In Pharmacy, Biology And Chemistry, 2(3), p. 473.

Pratiwi, E. W., Praharani, D. and Arina, Y. M. D. (2015) 'Daya Hambat Ekstrak Daun Pepaya (Carica papaya L.) terhadap Adhesi Bakteri Porphyromonas gingivalis pada Neutrofil', Pustaka Kesehatan, 3(2), pp. 193-198.

Rahayu, S. and Tjitraresmi, A. (2016) 'Review Artikel: Tanaman Pepaya (Carica papaya L.) dan Manfaatnya dalam Pengobatan', Jurnal Farmaka, 14(1).

Riswan, S. and Andayaningsih, D. (2008) 'Keanekaragaman Tumbuhan Obat yang Digunakan dalam Pengobatan Tradisional Masyarakat Sasak Lombok Barat', Jurnal Farmasi Indonesia, 4(2), pp. 96-103.

Saeed, A., Abd, H. and Sandstrom, G. (2015) 'Microbial Aetiology of Acute Diarrhoea in Children Under Five Years of Age in Khartoum, Sudan', Journal of medical microbiology. Microbiology Society, 64(4), pp. 432-437.

Setiati, S. et al. (2014) Buku Ajar Ilmu Penyakit Dalam. 6th edn, Interna Publishing. 6th edn. Jakarta.

Shehab, N. et al. (2016) 'US Emergency Department Visits for Outpatient Adverse Drug Events, 2013-2014', Jama. American Medical Association, 316(20), pp. 2115-2125.

Sidabutar, D. M., Kairupan, C. F. and Durry, M. (2016) 'Pengaruh Pemberian Ekstrak Daun Cengkeh (Syzygium aromaticum) Terhadap Gambaran Histopatologik Hati Tikus Wistar yang Diberikan Parasetamol DosisToksik', Jurnal e-Biomedik, 4(1).

Sugito and Suwandi, E. (2017) 'Efektifitas Ekstrak Ethanol Daun Pepaya (Carica Papaya L) terhadap Pertumbuhan Bakteri Escherichia coli dengan Metode Difusi', Jurnal Laboratorium Khatulistiwa, 1(1), pp. 21-25.

Tone, D. S., Wuisan, J. and Mambo, C. (2013) 'Uji Efek Analgesik Ekstrak Daun Mahkota Dewa (Phaleria Macrocarpa) Pada Mencit (Mus Musculus)', Jurnal e-Biomedik, 1(2), pp. 873878.

Tuntun, M. (2016) 'Uji Efektivitas Ekstrak Daun Pepaya (Carica papaya L.) Terhadap Pertumbuhan Bakteri Escherichia coli dan Staphylococcus aureus', Jurnal Kesehatan, 7(3), pp. 497-502.

Vijayakumar, M., Bharathidasan, R. and Prince, L. (2015) 'Antimicrobial Activity of Carica papaya L', Int J Arts Sci Res, 2, pp. 37-43.

World Health Organization (2017) 'Diarrhoeal Disease'. 
Siti Hartini, Eliya Mursyida / Jurnal Analis Kesehatan Klinikal Sains 7 (1) (2019)

Yunika, N. (2015) Uji Daya Hambat Ekstrak Daun Pepaya (Carica Papaya L.) Terhadap Pertumbuhan Bakteri Shigella dysenteriae. Palu. 